\title{
Review
}

\section{Bone age: assessment methods and clinical applications}

\author{
Mari Satoh \\ Department of Pediatrics, Toho University Omori Medical Center, Tokyo, Japan
}

\begin{abstract}
The main bone age assessment methods are the Greulich-Pyle and Tanner-Whitehouse 2 methods, both of which involve left hand and wrist radiographs. Several other bone age assessment methods have been developed, including ultrasonographic, computerized, and magnetic resonance (MR) imaging methods. The ultrasonographic method appears unreliable in children with delayed and advanced bone age. MR imaging is noninvasive; however, bone age assessment using MR imaging is relatively new, and further examinations are needed. An automated method for determining bone age, named BoneXpert, has been validated for Caucasian children with growth disorders and children of various ethnic groups. Sex hormones are necessary for bone growth and maturation in children with a bone age corresponding to normal pubertal age, and estrogen is essential for growth plate closure. Bone age is an effective indicator for diagnosing and treating various diseases. A new method for adult height prediction based on bone age has been developed using BoneXpert, in addition to the commonly used Bayley-Pinneau and Tanner-Whitehouse mark II methods. Furthermore, bone age may become a predictor for the timing of peak height velocity and menarche.
\end{abstract}

Key words: bone age, growth, maturation, prediction, adult height

\section{Introduction}

Bone age assessment is frequently performed not only in pediatric endocrinology but also in orthodontics and pediatric orthopedics. Bone age is an effective indicator for diagnosing various diseases and determining the timing of treatment. The aim of bone age assessment is to evaluate growth and maturity and to diagnose and manage pediatric disorders. Therefore, the accuracy of

Received: April 6, 2015

Accepted: July 1, 2015

Corresponding author: Mari Satoh, Department of Pediatrics, Toho University Omori Medical Center, 6-11-1 Omori-nishi, Ota-ku, Tokyo 143-8541, Japan

E-mail: satomari@med.toho-u.ac.jp

This is an open-access article distributed under the terms of the Creative Commons Attribution Non-Commercial No Derivatives (by-nc-nd) License < http://creativecommons.org/ licenses/by-nc-nd/3.0/>. bone age assessment is very important. Although manual bone age assessment methods have been used for a long time, the main problem with these methods is inter- and intra-observer variability. Recently, several computerized systems for bone age assessment have been developed. In this review, I describe the progress in assessment methods and clinical applications of bone age.

\section{Bone Age Assessment Methods}

The most commonly used bone age assessment methods are the Greulich-Pyle (GP) (1) and Tanner-Whitehouse 2 (TW2) (2) methods, both of which involve left hand and wrist radiographs. Radiographs of the hand and wrist are suitable for bone age assessment because the hand and wrist possess many bones and taking radiographs of the hand and wrist 
is easy. There are several reasons for using left hand and wrist radiographs for bone age assessment rather than right hand and wrist radiographs. One reason is that most people are right-handed, and therefore, the right hand is more likely to be injured than the left hand (1). Another reason is that it was determined that physical measurements should be performed on the left side rather than the right side of the body at the conferences of physical anthropologists in the early 1900s (1).

The hand and wrist bones consist of the radius, ulna, 19 short bones (5 metacarpals and 14 phalanges) and 7 carpals. Bones are formed by endochondral ossification in the radius, ulna and short bones and by intramembranous ossification in the carpal bones. The maturation rates of the carpals vary among individuals. The completion of maturation occurs earlier in the carpals compared with the long and short bones, and intramembranous ossification is less dependent on GH than endochondral ossification. Therefore, the carpals are not suitable for bone age assessment.

Although the bone maturation process itself is similar among all people, the rate of bone maturation differs among ethnic groups. The main cause of the difference in bone maturation rate among ethnic groups is the difference in the timing of pubertal onset (3).

\section{GP method}

The GP method is an atlas method in which bone age is evaluated by comparing the radiograph of the patient with the nearest standard radiograph in the atlas. The GP method was developed using radiographs of uppermiddle class Caucasian children in Cleveland, Ohio, United States, and the radiographs were obtained between 1931 and 1942. It has recently been reported that secondary sex characteristics in current boys and girls begin earlier than they did several decades ago in the United States (4, 5); therefore, it may be difficult to assess bone age accurately in current children using the GP method.

\section{TW2 methods}

There are actually three different TW2 methods: the radius-ulna-short bones (RUS) method for evaluating the 13 long or short bones (i.e., the radius, ulna and short bones of the first, third and fifth fingers), the carpal method for evaluating the 7 carpals and the 20-bones method for evaluating the 13 long or short bones and 7 carpals. For the purposes of this review, the TW2 methods are referred to as the TW2 method hereafter. The TW2 method is a scoring method. Firstly, the maturity level of each bone is categorized into a stage (from stage $\mathrm{A}$ to $\mathrm{H}$ or I). Afterwards, each stage is replaced by a score, and a total sore is calculated. Finally, the total score is transformed into the bone age.

The TW2 method was developed using radiographs of average socioeconomic class children in the United Kingdom, and the radiographs were collected in the 1950s and 1960s. The Tanner-Whitehouse 3 (TW3) method, which was developed to update the relationship between the total bone maturity score and bone age based on secular trends, was published in 2001 (6). Standardized Tanner-Whitehouse (TW) methods have been reported in several countries, and these methods have changed the relationship between the total bone maturity score and bone age to make the relationship suitable for each generation and ethnic group (7-9).

The standard deviation of bone age calculated using the RUS method was approximately 1 year from the age of 5 years in both sexes to $14 \mathrm{yr}$ in girls and $16 \mathrm{yr}$ in boys (2).

\section{Comparison between the GP and TW2 methods}

The scoring method of the TW2 method is more objective than the atlas method, and therefore, the TW2 method is considered to have higher reproducibility than the GP method. Bull et al. (10) reported that the intra-observer variation was greater for the GP method than 
Table 1. Characteristics of representative bone age assessment methods

\begin{tabular}{|c|c|c|c|}
\hline & Image type & Evaluation structures & Method \\
\hline $\begin{array}{l}\text { Conventional method } \\
\text { Greulich-Pyle } \\
\text { Tanner-Whitehouse } 2\end{array}$ & $\begin{array}{l}\text { Radiograph } \\
\text { Radiograph }\end{array}$ & $\begin{array}{l}\text { Hand and wrist bones } \\
\text { RUS, carpal and } 20 \text { bones }\end{array}$ & $\begin{array}{l}\text { Atlas method } \\
\text { Scoring method }\end{array}$ \\
\hline $\begin{array}{l}\text { Ultrasonographic method } \\
\text { BonAge }{ }^{\circledR}\end{array}$ & Ultrasonogram & Radius and ulnar epiphysis & Sound velocity measurement \\
\hline $\begin{array}{l}\text { MR imaging method } \\
\text { Open compact MR imager }\end{array}$ & MR image & RUS & Scoring method \\
\hline $\begin{array}{l}\text { Computerized method } \\
\text { CASAS }\end{array}$ & Radiograph & RUS, carpal and 20 bones & $\begin{array}{l}\text { Computer-assisted scoring } \\
\text { method }\end{array}$ \\
\hline CASMAS & Radiograph & Third phalanges & $\begin{array}{l}\text { Automated computerized } \\
\text { calculation }\end{array}$ \\
\hline BoneXpert & Radiograph & RUS & $\begin{array}{l}\text { Automated computerized } \\
\text { calculation }\end{array}$ \\
\hline
\end{tabular}

RUS, radius, ulna and short bones; MR, magnetic resonance. CASAS, computer-assisted skeletal age score; CASMAS, computer-aided skeletal maturity system.

the TW2 method (95\% confidence interval, -2.46 to 2.18 vs. -1.48 to 1.43 , respectively). However, assessment using the TW2 method required a longer time than the GP method. King et al. reported that the average time required for TW2 and GP assessments was $7.9 \mathrm{~min}$ and $1.4 \mathrm{~min}$, respectively (11).

\section{Other methods}

Recently, new methods for bone age assessment have been developed, including ultrasonographic, computerized and magnetic resonance (MR) imaging methods (Table 1).

Ultrasonographic method: There are several reports regarding ultrasonographic evaluation of bone age using an instrument called BonAge ${ }^{\circledR}$ (Sunlight Medical Ltd, Tel Aviv, Israel). This instrument utilizes an armrest between two transducers to support the subject's hand and wrist, and ultrasonic waves pass through the subject's distal radius and ulnar epiphysis. Afterwards, software is used to calculate the bone age using an algorithm based on measurements of sound velocity and the distance between the two transducers. Both Mentzel et al. (12) and Shimura et al. (13) reported that there were high correlations between the bone age evaluated by BonAge ${ }^{\circledR}$ and the GP or TW2 methods. In contrast, Khan et al. (14) reported that BonAge ${ }^{\circledR}$ tended to over-read delayed bone age and under-read advanced bone age compared with both the GP and TW3 methods; they concluded that BonAge ${ }^{\circledR}$ should not be considered a valid replacement for determining radiographic bone age. Further studies of bone age assessment by ultrasonography are needed in larger populations, different ethnic groups and children with growth disorders.

Computerized method: Several computerized systems for bone age assessment have been reported. Some of these systems were developed based on the TW method (15-17). One example is the computer-assisted skeletal age score (CASAS) (15), in which an image is digitized and represented by several mathematical coefficients. These coefficients are then compared to those generated by each stage of the TW standards, and the closest match is determined. Although CASAS has been reported to be more reliable than the manual methods $(18,19)$, a limitation 
of CASAS is that it can take longer to estimate bone age than the manual methods because each bone has to be located manually.

Alternatively, Sato et al. (20) reported a new system that can automatically evaluate the bone maturation of Japanese children, the computeraided skeletal maturity system (CASMAS), which is not based on the TW method. In CASMAS, digital images of the third phalanges are automatically extracted from computerized scans of a hand and wrist radiograph, and the widths of the epiphyses, metaphyses and overlapping regions of the epiphysis and metaphysis in the third phalanges are automatically measured. The results are then used to calculate bone age by multiple regression analysis.

Another automated method has recently been developed, called BoneXpert (Visiana, Denmark) (21). In BoneXpert, the borders of 13 RUS bones (radius, ulna and 11 short bones in fingers 1, 3 and 5) are automatically determined from a digitized image (Layer A), and an intrinsic bone age is calculated from parameters such as shape scores, bone density scores and features describing the texture of the fusion in the growth plate (Layer B). Normal Danish children in 1966 participated in the development of Layer B. The intrinsic bone age is then transformed into the GP bone age or TW bone age (Layer C). This automated bone age determination system has been validated in Caucasian children with short statures (22) and precocious puberty (23). Moreover, the usefulness of this system has been reported for various ethnic groups (24, $25)$, especially by calibration to the standard for Japanese children $(26,27)$.

MR imaging method: Terada et al. $(28,29)$ reported the usefulness of bone age assessment using MR images of the hand and wrist compared with radiographs. They used an open compact MR imager with a permanent magnet that was newly developed as a pediatric hand scanner to evaluate bone age. Although MR imaging is a noninvasive method, one can requires a long time ( $2 \mathrm{~min}$ and $44 \mathrm{sec}$ ). Therefore, this method may not be suitable for some subjects, especially young children, due to body movement.

\section{Bone Growth and Maturation}

\section{Bone age}

Bone age represents the degree of secondary ossification in long and short bones, which are formed by endochondral ossification. A cartilaginous growth plate between the epiphysis and metaphysis is responsible for postnatal linear bone growth (30). Chondrocytes in the growth plate not only proliferate but also differentiate. The resting zone consists of undifferentiated chondrocyte progenitors, which differentiate into proliferative chondrocytes and then into hypertrophic chondrocytes. Finally, hypertrophic chondrocyte apoptosis occurs after blood vessels invade into the hypertrophic zone, and osteoblasts then migrate into the cartilage matrix to form bone.

Male patients with estrogen resistance and aromatase deficiency showed incomplete epiphyseal closure with histories of continued linear growth in adulthood $(31,32)$; therefore, it has been demonstrated that estrogen is essential for growth plate closure in both men and women. Nilsson et al. (33) reported that estrogen caused irreversible depletion of chondrocyte progenitors in the resting zone of rabbits.

\section{Delayed and accelerated bone age}

Chondrocyte proliferation and differentiation and the conversion of chondrocytes to osteoblasts are accelerated by GH, IGF-I, thyroid hormone, estrogen and androgen and suppressed by glucocorticoid (34). Therefore, deficiencies in GH, IGF-I, thyroid hormone, estrogen and androgen and excess glucocorticoid cause both growth impairment and bone age delay. In contrast, overproduction of GH, IGF-I, thyroid hormone, estrogen and androgen causes both overgrowth and bone age advancement. Bone age advancement is often recognized in children with obesity. It has been reported that bone 
maturation was accelerated after puberty onset in obese children compared with nonobese children $(35,36)$. It has also been suggested that hyperestrogenemia contributes to the advancement of bone maturation in obese boys (36).

\section{Growth and maturation of bone and sex hormones}

A deceleration of height velocity and bone age maturation rate is often recognized in children with delayed puberty. The same phenomenon is also recognized in children with central precocious puberty during LHRH analogue treatment. Weise et al. (37) reported that the mean height velocity in girls with central precocious puberty during $\mathrm{LHRH}$ analogue treatment was low for bone age in those with a bone age of $\geq 10 \mathrm{yr}$, but not for those with a bone age of $<10 \mathrm{yr}$. They suggested that estrogen was required for growth in girls with a bone age of $\geq$ $10 \mathrm{yr}$ because girls with a bone age of $\geq 10 \mathrm{yr}$ are usually undergoing puberty during that time.

Tanaka et al. (38) reported that in children with GH deficiency treated with a combination of $\mathrm{GH}$ and an LHRH analogue, the bone age maturation rate during the combination treatment decelerated after a bone age of 11.5 yr in boys and $10.5 \mathrm{yr}$ in girls and bone age did not exceed $14 \mathrm{yr}$ in boys and $13 \mathrm{yr}$ in girls. The bone age maturation rate in untreated Turner girls without puberty decelerated after a bone age of $10 \mathrm{yr}$ and never exceeded a bone age of 13 yr (39). Moreover, the mean bone age maturation rates in Turner girls without puberty during GH treatment $(0.175-0.35 \mathrm{mg} / \mathrm{kg} / \mathrm{w})$ were $1.11 \pm 0.49$ yr per chronological age before a bone age of 10.0 yr and $0.45 \pm 0.35$ yr per chronological age after a bone age of $10.0 \mathrm{yr}(40)$.

It has been suggested that sex hormones are necessary for bone growth and maturation in children with a bone age corresponding to normal pubertal age. A sex hormone, probably estrogen, is essential for growth plate closure.

\section{Clinical Applications of Bone Age}

\section{Relationship between bone age and indica- tors of puberty}

Bone age at puberty onset: Flor-Cisneros et al. (41) reported that the onset of central puberty occurred at an abnormal chronological age but at a normal bone age in boys with congenital adrenal hyperplasia, familial male-limited precocious puberty and idiopathic short stature. Therefore, they suggested that the hypothalamic-pituitarygonadal axis maturation might be regulated by somatic growth and maturation in the bone itself or in nonskeletal tissues that paralleled bone growth and maturation.

However, it has been reported that the variability in bone age at puberty onset in both normal boys and girls was not less than the variability in chronological age (42-44). Therefore, it may be difficult to predict the timing of pubertal onset in normal children using bone age.

Bone age at peak height velocity: Predicting the timing of peak height velocity (PHV) is important in patients with scoliosis, kyphosis and slipped capital femoral epiphysis for determination of the timing of surgical treatment and in patients with growth disorders for prediction of adult height and modification of treatment.

Satoh et al. (44) reported that bone age at PHV evaluated by the Japanese TW2-RUS method was distributed at about 13 and $11 \mathrm{yr}$ in normal Japanese boys and girls, respectively; these ages were equivalent to the ages at PHV on standard growth velocity curves for Japanese children. Pitlovic et al. (45) reported that the olecranon apophysis maturity level assessed by ultrasound could predict the timing of PHV in healthy children. Although further examinations are needed, bone age may be a predictor for the timing of PHV.

Bone age at menarche: Lai et al. (46) reported that menarche occurred after cervical vertebral maturation stage (CVMS) III based on 
lateral cephalometric radiographs in orthodontic patients. Satoh (47) reported that the onset of menstruation was at a bone age of approximately 12 yr, as evaluated by the Japanese TW2RUS method in Japanese girls, regardless of the chronological age at the onset of puberty. This bone age was equivalent to the mean chronological age (12 yr and $4 \mathrm{mo}$ ) at menarche in Japanese girls. Bone age may be one of the indicators for predicting the timing of menarche.

\section{Prediction of adult height}

Prediction of adult height is very important in pediatric endocrinology. The commonly used methods for adult height prediction based on bone age are the Bayley-Pinneau (48) and TW mark II (2) methods. However, the accuracy of adult height prediction methods based on bone age has been reported to vary based on the cause of growth disorders such as normal short stature $(49,50)$, constitutional delay of growth and puberty $(50,51)$, idiopathic short stature (52) and constitutional tall stature $(53,54)$. This variability is due to several reasons. Firstly, the commonly used height prediction methods involve the data of children with normal height, and therefore, these methods are suitable for children with normal height, but not for children with growth disorders (55). Both the BayleyPinneau and TW mark II methods overestimate the adult height of short children. Secondly, the accuracy of height prediction methods based on bone age contributes to the accuracy of bone age assessment; however, rater variability is high in manual bone age assessment methods. Finally, a major source of error is the inability to predict the timing of the pubertal growth spurt (55).

Tanaka et al. (56) established a new adult height prediction method for pubertal short children, the Growth Potential II method, by retrospectively analyzing the natural growth of short children. It is difficult to predict the adult height of prepubertal children because adult height is significantly affected by the timing of pubertal onset.Therefore, the target subjects of the Growth Potential II method are pubertal children. The height difference between the observed and predicted adult height is defined as the growth potential, which is calculated by a multiple regression formula using the following factors: chronological age, bone age, height and weight at the time of observation, and chronological age and height at the onset of puberty. The predicted adult height is then obtained by adding the growth potential to the observed height. The Growth Potential II method was subsequently reevaluated, and the absolute values of the differences between predicted adult height and actual adult height were $2.4 \pm 1.7 \mathrm{~cm}$ $(0.1-5.9 \mathrm{~cm})$ in 24 short boys and $2.4 \pm 1.8 \mathrm{~cm}$ $(0-7.4 \mathrm{~cm})$ in 20 short girls $(57)$.

Recently, Thodberg et al. (58) reported a new adult height prediction method based on BoneXpert bone age. In this method, the predicted adult height $\left(\mathrm{H}_{\text {raw }}\right)$ is calculated using height, chronological age, and bone age based on the same concept as the Bayley-Pinneau method. The final predicted adult height is then obtained after modifying $\mathrm{H}_{\text {raw }}$ using the parents' heights or the population standard height, and the weight and body mass index (BMI) of the patient. It has been reported that this new method performs significantly better than the Bayley-Pinneau method in children with idiopathic short stature (59).

A summary of the clinical applications of bone age is shown in Table 2, and the characteristics of adult height prediction methods are shown in Table 3.

\section{Conclusions}

An automated bone age determination method (BoneXpert) was developed and validated in Caucasian children with various growth disorders. Moreover, this method has been reported to be useful for bone age assessment in other ethnic groups by calibration to other ethnic standards, which in turn increases the usefulness of bone age. Bone age has already 
Table 2. Clinical applications of bone age

\begin{tabular}{ll}
$\begin{array}{l}\text { 1. Bone age and sex hormones } \\
\text { Sex hormones }\end{array}$ & $\begin{array}{c}\text { Necessary for bone maturation after a bone age } \\
\text { corresponding to normal pubertal age } \\
\text { Essential for growth plate closure }\end{array}$ \\
\hline Estrogen & $\begin{array}{l}\text { Not available in normal children } \\
\text { Onset of puberty }\end{array}$ \\
Timing of peak height velocity & $\begin{array}{l}\text { Probably available } \\
\text { Probably available }\end{array}$ \\
Menarche & \\
$\begin{array}{l}\text { 3. Adult height prediction methods based on bone age } \\
\text { Bayley-Pinneau }\end{array}$ & \\
Tanner-Whitehouse mark II & \\
Growth Potential II & \\
A method based on BoneXpert bone age
\end{tabular}

Table 3. Characteristics of adult height prediction methods

\begin{tabular}{|c|c|c|}
\hline Method & Target subjects & Limitations \\
\hline Bayley-Pinneau & Normal height children & Not suitable for children with short stature \\
\hline Tanner-Whitehouse mark II & Normal height children & Not suitable for children with short stature \\
\hline Growth Potential II & Short pubertal children & $\begin{array}{l}\text { Chronological age and height at the onset of } \\
\text { puberty are needed. }\end{array}$ \\
\hline $\begin{array}{l}\text { A method based on BoneXpert } \\
\text { bone age }\end{array}$ & $\begin{array}{l}\text { Normal height children } \\
\text { Children with idiopathic } \\
\text { short stature }\end{array}$ & BoneXpert software is needed. \\
\hline
\end{tabular}

been used as an indicator for diagnosis and treatment and as a predictor for adult height. In addition, bone age may become a predictor for the timing of pubertal peak height velocity and menarche.

\section{References}

1. Greulich WW, Pyle SI. Radiograph atlas of skeletal development of the hand and wrist. 2nd ed. California: Stanford University Press;1959.

2. Tanner JM, Whitehouse RH, Cameron $\mathrm{N}$, Marshall WA, Healy MJ, Goldstein H. Assessment of skeletal maturity and prediction of adult height (TW2 method). London: Academic Press;1983.

3. Ashizawa K, Asami T, Anzo M, Matsuo N, Matsuoka H, Murata M, et al. Standard RUS skeletal maturation of Tokyo children. Ann Hum
Biol 1996;23: 457-69. [Medline] [CrossRef]

4. Euling SY, Herman-Giddens ME, Lee PA, Selevan SG, Juul A, Sørensen TI, et al. Examination of US puberty-timing data from 1940 to 1994 for secular trends: panel findings. Pediatrics 2008;121(Suppl 3): S172-91. [Medline] [CrossRef]

5. Herman-Giddens ME, Steffes J, Harris D, Slora E, Hussey M, Dowshen SA, et al. Secondary sexual characteristics in boys: data from the Pediatric Research in Office Settings Network. Pediatrics 2012;130: e1058-68. [Medline] [CrossRef]

6. Tanner JM, Healy M, Goldstein H, Cameron N. Assessment of skeletal maturity and prediction of adult height (TW3 method). 3rd ed. London: WB Saunders, Harcourt Publishers Ltd;2001.

7. Beunen G, Lefevre J, Ostyn M, Renson R, Simons J, Van Gerven D. Skeletal maturity in Belgian 
youths assessed by the Tanner-Whitehouse method (TW2). Ann Hum Biol 1990;17: 355-76. [Medline] [CrossRef]

8. Murata M. Japanese specific bone age standard on the TW2. Clin Pediatr Endocrinol 1993;2(Suppl 3): 35-41. [CrossRef]

9. Tanner J, Oshman D, Bahhage F, Healy M. Tanner-Whitehouse bone age reference values for North American children. J Pediatr 1997;131: 34-40. [Medline] [CrossRef]

10. Bull RK, Edwards PD, Kemp PM, Fry S, Hughes IA. Bone age assessment: a large scale comparison of the Greulich and Pyle, and Tanner and Whitehouse (TW2) methods. Arch Dis Child 1999;81: 172-3. [Medline] [CrossRef]

11. King DG, Steventon DM, O'Sullivan MP, Cook AM, Hornsby VP, Jefferson IG, et al. Reproducibility of bone ages when performed by radiology registrars: an audit of Tanner and Whitehouse II versus Greulich and Pyle methods. Br J Radiol 1994;67: 848-51. [Medline] [CrossRef]

12. Mentzel HJ, Vilser C, Eulenstein M, Schwartz $\mathrm{T}$, Vogt S, Böttcher J, et al. Assessment of skeletal age at the wrist in children with a new ultrasound device. Pediatr Radiol 2005;35: 429-33. [Medline] [CrossRef]

13. Shimura N, Koyama S, Arisaka O, Imataka M, Sato K, Matsuura M. Assessment of measurement of children's bone age ultrasononically with Sunlight BonAge. Clin Pediatr Endocrinol 2005;14(Suppl 24): 17-20. [CrossRef]

14. Khan KM, Miller BS, Hoggard E, Somani A, Sarafoglou K. Application of ultrasound for bone age estimation in clinical practice. J Pediatr 2009;154: 243-7. [Medline] [CrossRef]

15. Tanner JM, Gibbons RD. Automatic bone age measurement using computerized image analysis. J Pediatr Endocrinol 1994;7: 141-5. [Medline] [CrossRef]

16. Drayer NM, Cox LA. Assessment of bone ages by the Tanner-Whitehouse method using a computer-aided system. Acta Paediatr Suppl 1994;406: 77-80. [Medline] [CrossRef]

17. Rucci M, Coppini G, Nicoletti I, Cheli D, Valli G. Automatic analysis of hand radiographs for the assessment of skeletal age: a subsymbolic approach. Comput Biomed Res 1995;28: 239-56.
[Medline] [CrossRef]

18. Tanner JM, Oshman D, Lindgren G, Grunbaum JA, Elsouki R, Labarthe D. Reliability and validity of computer-assisted estimates of Tanner-Whitehouse skeletal maturity (CASAS): comparison with the manual method. Horm Res 1994;42: 288-94. [Medline] [CrossRef]

19. Frisch H, Riedl S, Waldhör T. Computer-aided estimation of skeletal age and comparison with bone age evaluations by the method of GreulichPyle and Tanner-Whitehouse. Pediatr Radiol 1996;26: 226-31. [Medline] [CrossRef]

20. Sato K, Ashizawa K, Anzo M, Otsuki F, Kaneko $\mathrm{S}$, Tanaka T, et al. Setting up an automated system for evaluation of bone age. Endocr J 1999;46(Suppl): S97-100. [Medline] [CrossRef]

21. Thodberg HH, Kreiborg S, Juul A, Pedersen KD. The BoneXpert method for automated determination of skeletal maturity. IEEE Trans Med Imaging 2009;28: 52-66. [Medline] [CrossRef]

22. Martin DD, Deusch D, Schweizer R, Binder G, Thodberg HH, Ranke MB. Clinical application of automated Greulich-Pyle bone age determination in children with short stature. Pediatr Radiol 2009;39: 598-607. [Medline] [CrossRef]

23. Martin DD, Meister K, Schweizer R, Ranke MB, Thodberg HH, Binder G. Validation of automatic bone age rating in children with precocious and early puberty. J Pediatr Endocrinol Metab 2011;24: 1009-14. [Medline] [CrossRef]

24. Thodberg HH, Sävendahl L. Validation and reference values of automated bone age determination for four ethnicities. Acad Radiol 2010;17: 1425-32. [Medline] [CrossRef]

25. Zhang SY, Liu G, Ma CG, Han YS, Shen XZ, Xu $\mathrm{RL}$, et al. Automated determination of bone age in a modern Chinese population. ISRN Radiol 2013;2013: 874570. doi: 10.5402/2013/874570.

26. Martin DD, Sato K, Sato M, Thodberg HH, Tanaka T. Validation of a new method for automated determination of bone age in Japanese children. Horm Res Paediatr 2010;73: 398-404. [Medline] [CrossRef]

27. Ogasawara A, Sato N, Tanaka T. Comparison of TW2 bone age estimations between BoneXpert and atlas method in new patients visited a clinic for growth disorders. J Jpn Ass Hum Auxo 
2015;21: 50-9 (In Japanese).

28. Terada Y, Kono S, Tamada D, Uchiumi T, Kose $\mathrm{K}$, Miyagi R, et al. Skeletal age assessment in children using an open compact MRI system. Magn Reson Med 2013;69: 1697-702. [Medline] [CrossRef]

29. Terada Y, Kono S, Uchiumi T, Kose K, Miyagi $\mathrm{R}$, Yamabe $\mathrm{E}$, et al. Improved reliability in skeletal age assessment using a pediatric hand MR scanner with a $0.3 \mathrm{~T}$ permanent magnet. Magn Reson Med Sci 2014;13: 215-9. [Medline] [CrossRef]

30. Mackie EJ, Tatarczuch L, Mirams M. The skeleton: a multi-functional complex organ: the growth plate chondrocyte and endochondral ossification. J Endocrinol 2011;211: 109-21. [Medline] [CrossRef]

31. Smith EP, Boyd J, Frank GR, Takahashi H, Cohen RM, Specker B, et al. Estrogen resistance caused by a mutation in the estrogen-receptor gene in a man. N Engl J Med 1994;331: 1056-61. [Medline] [CrossRef]

32. Morishima A, Grumbach MM, Simpson ER, Fisher C, Qin K. Aromatase deficiency in male and female siblings caused by a novel mutation and the physiological role of estrogens. J Clin Endocrinol Metab 1995;80: 3689-98. [Medline]

33. Nilsson O, Weise M, Landman EB, Meyers JL, Barnes KM, Baron J. Evidence that estrogen hastens epiphyseal fusion and cessation of longitudinal bone growth by irreversibly depleting the number of resting zone progenitor cells in female rabbits. Endocrinology 2014;155: 2892-9. [Medline] [CrossRef]

34. Nilsson O, Marino R, De Luca F, Phillip M, Baron J. Endocrine regulation of the growth plate. Horm Res 2005;64: 157-65. [Medline] [CrossRef]

35. Johnson W, Stovitz SD, Choh AC, Czerwinski SA, Towne B, Demerath EW. Patterns of linear growth and skeletal maturation from birth to 18 years of age in overweight young adults. Int J Obes (Lond) 2012;36: 535-41. [Medline] [CrossRef]

36. Vandewalle S, Taes Y, Fiers T, Van Helvoirt M, Debode P, Herregods N, et al. Sex steroids in relation to sexual and skeletal maturation in obese male adolescents. J Clin Endocrinol Metab 2014;99: 2977-85. [Medline] [CrossRef]
37. Weise M, Flor A, Barnes KM, Cutler GB Jr, Baron J. Determinants of growth during gonadotropin-releasing hormone analog therapy for precocious puberty. J Clin Endocrinol Metab 2004;89: 103-7. [Medline] [CrossRef]

38. Tanaka T, Satoh M, Yasunaga T, Horikawa R, Tanae A, Katsumata N, et al. When and how to combine growth hormone with a luteinizing hormone-releasing hormone analogue. Acta Paediatr Suppl 1999;88: 85-8. [Medline] [CrossRef]

39. Tanaka T, Satoh M, Tanae A, Hibi I. Bone age maturation during growth promoting and $\mathrm{GnRHa}$ treatment in Turner syndrome. In: AlbertssonWikland K, Ranke M, editors. Turner Syndrome in a Life-Span Perspective. Amsterdam: Elsevier Science B.V.;1995.p.191-200.

40. Satoh M, Naiki Y, Horikawa R, Tanaka T. Effect of growth hormone on bone age maturation in children with Turner syndrome. J Jpn Ass Hum Auxo 2005;11: 9-13 (In Japanese).

41. Flor-Cisneros A, Leschek EW, Merke DP, Barnes $\mathrm{KM}$, Coco M, Cutler GB Jr, et al. In boys with abnormal developmental tempo, maturation of the skeleton and the hypothalamic-pituitarygonadal axis remains synchronous. J Clin Endocrinol Metab 2004;89: 236-41. [Medline] [CrossRef]

42. Flor-Cisneros A, Roemmich JN, Rogol AD, Baron $\mathrm{J}$. Bone age and onset of puberty in normal boys. Mol Cell Endocrinol 2006;254-5: 202-6. [Medline] [CrossRef]

43. Marshall WA. Interrelationships of skeletal maturation, sexual development and somatic growth in man. Ann Hum Biol 1974;1: 29-40. [Medline] [CrossRef]

44. Satoh M, Tanaka T. Bone age at onset of pubertal growth spurt and final height in normal children. Clin Pediatr Endocrinol 1995;4: 129-36. [CrossRef]

45. Pitlović V, Sarić G, Pitlović H, Jovanović S, Jurisić D. A correlation of peak height velocity and olecranon apophysis ossification assessed by ultrasound. Coll Antropol 2013;37: 1285-9. [Medline]

46. Lai EH, Chang JZ, Jane Yao CC, Tsai SJ, Liu JP, Chen YJ, et al. Relationship between age at menarche and skeletal maturation stages 
in Taiwanese female orthodontic patients. $\mathrm{J}$ Formos Med Assoc 2008;107: 527-32. [Medline] [CrossRef]

47. Satoh M. Prediction of the age at menarche using bone age. J Jpn Ass Hum Auxo 2013;19: 71-5 (In Japanese).

48. Bayley N, Pinneau SR. Tables for predicting adult height from skeletal age: revised for use with the Greulich-Pyle hand standards. J Pediatr 1952;40: 423-41. [Medline] [CrossRef]

49. Maes M, Vandeweghe M, Du Caju M, Ernould C, Bourguignon JP, Massa G. A valuable improvement of adult height prediction methods in short normal children. Horm Res 1997;48: 184-90. [Medline] [CrossRef]

50. Brämswig JH, Fasse M, Holthoff ML, von Lengerke HJ, von Petrykowski W, Schellong G. Adult height in boys and girls with untreated short stature and constitutional delay of growth and puberty: accuracy of five different methods of height prediction. J Pediatr 1990;117: 886-91. [Medline] [CrossRef]

51. Sperlich M, Butenandt O, Schwarz HP. Final height and predicted height in boys with untreated constitutional growth delay. Eur J Pediatr 1995;154: 627-32. [Medline] [CrossRef]

52. Topor LS, Feldman HA, Bauchner H, Cohen LE. Variation in methods of predicting adult height for children with idiopathic short stature. Pediatrics 2010;126: 938-44. [Medline] [CrossRef]

53. Joss EE, Temperli R, Mullis PE. Adult height in constitutionally tall stature: accuracy of five different height prediction methods. Arch Dis Child 1992;67: 1357-62. [Medline] [CrossRef]

54. de Waal WJ, Greyn-Fokker MH, Stijnen T, van Gurp EA, Toolens AM, de Munick KeizerSchrama SM, et al. Accuracy of final height prediction and effect of growth-reductive therapy in 362 constitutionally tall children. J Clin Endocrinol Metab 1996;81: 1206-16. [Medline]

55. Preece MA. Prediction of adult height: methods and problems. Acta Paediatr Scand Suppl 1988;347: 4-11. [Medline]

56. Tanaka T, Naiki Y, Horikawa R, Satoh M. Adult height prediction method for pubertal short children (Growth Potential II Method). J Jpn Ass Hum Auxo 2009;15: 17-22 (In Japanese).

57. Tanaka T, Ogawa M, Nose O, Kamijo T, Kinoshita E, Ogawa $\mathrm{H}$, et al. Reevaluation of Growth Potential II Method in pubertal short children. J Jpn Ass Hum Auxo 2014;20: 30-5 (In Japanese).

58. Thodberg HH, Jenni OG, Caflisch J, Ranke MB, Martin DD. Prediction of adult height based on automated determination of bone age. J Clin Endocrinol Metab 2009;94: 4868-74. [Medline] [CrossRef]

59. Unrath M, Thodberg HH, Schweizer R, Ranke MB, Binder G, Martin DD. Automation of bone age reading and a new prediction model improve adult height prediction in children with short stature. Horm Res Paediatr 2012;78: 312-9. [Medline] [CrossRef] 